\title{
Öğrenci Ebelerde Empatik Eğilim ve Özgeciliğin İncelenmesi*
}

\author{
Şükran ERTEKIN PINAR ${ }^{1}$, Gülay YILDIRIM [i] ${ }^{2}$
}

ÖZ

Amaç: $\mathrm{Bu}$ araştırma öğrenci ebelerde empatik eğilim ve özgeciliğin incelenmesi amacı ile yapılmıştır.

Gereç ve Yöntemler: Tanımlayıcı araştırmanın örneklemini 251 öğrenci ebe oluşturmuştur. Veriler Kişisel Bilgi Formu, Empatik Eğilim Ölçeği ve Özgecilik Ölçeği ile toplanmıştır. Verilerin istatiksel değerlendirilmesinde bağımsız örneklem $t$ testi, tek yönlü varyans analizi, Tukey testi ve Pearson korelasyon analizi kullanılmıştır.

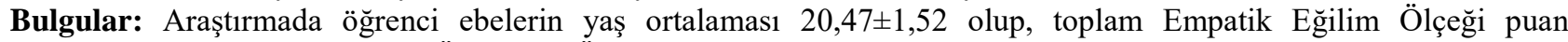
ortalaması $71,23 \pm 7,94$, toplam Özgecilik Ölçeği puan ortalaması $68,42 \pm 9,88$ olarak saptanmıştır. Toplam Empatik Eğilim Ölçeği puan ortalaması ile toplam Özgecilik Ölçeği puan ortalaması arasında pozitif yönlü istatistiksel olarak anlamlı bir ilişki vardır $(\mathrm{r}=0,335 ; \mathrm{p}<0,001)$. Öğrenci ebelerin öğrenim gördüğü sınıf, mesleği kendisine uygun bulma ve hastaları anlayabilme becerisine göre toplam Empatik Eğilim Ölçeği puan ortalamaları arasında, öğrenimi sırasında yaşadığı yere, mesleği kendisine uygun bulma ve hastaları anlayabilme becerisine göre Özgecilik Ölçeği puan ortalamaları arasında istatistiksel olarak anlamlı fark vardır $(\mathrm{p}<0,05)$.

Sonuç: Öğrenci ebelerin empatik eğilim ve özgecilik düzeyleri ortalamanın üzerindedir. Öğrencilerin empatik eğilimleri arttıkça özgecilik düzeyleri de artmaktadır. Mesleği kendisine çok uygun bulan ve hastaları "her zaman" anlayabildiğini belirten öğrenci ebelerin empatik eğilim ve özgecilik düzeyleri daha yüksektir. Mezuniyet aşamasında olan öğrenci ebelere özgecilik ve empatik eğilim becerilerine yönelik seminer, kurs gibi destekleyici aktivitelerin yapılması önerilmektedir.

Anahtar Kelimeler: Ebelik; Eğitim; Empatik; Özgecilik.

\section{Examination of Empathic Tendency and Altruism in Midwifery Students}

\begin{abstract}
Aim: This research was conducted to examine the empathic tendency and altruism in midwife candidates.

Material and Methods: The sample of this descriptive study composed of 251 midwifery students. Data were collected with the Personal Information Form, the Empathic Tendency Scale, and the Altruism Scale. In the statistical evaluation of the data, independent sample t test, one-way analysis of variance, Tukey test, Pearson Correlation analysis were used. Results: The mean age of the midwifery students was 20.47 \pm 1.52 , the mean score of the total Empathic Tendency Scale was $71.23 \pm 7.94$, and the mean score of the total Altruism Scale was $68.42 \pm 9.88$. There was a positive statistically significant correlation between students' total Empathic Tendency Scale scores and total altruism scale scores ( $\mathrm{r}=0.335$; $\mathrm{p}<0.001$ ). There was a statistically significant difference between total Empathic Tendency Scale scores and grade of students, their suitability to the profession itself, and their ability to understand patients, and between the total altruism scores and place of residence during university education, their suitability to the profession itself, and their ability to understand patients $(\mathrm{p}<0.05)$.

Conclusion: The empathic tendency and altruism levels of the students were found to be above the average. As students' empathic tendencies increase, altruism levels increase. Empathic tendencies and altruistic levels of students who find the profession very suitable and who indicate that they can "always" understand patients are higher.
\end{abstract}

1 Sivas Cumhuriyet Üniversitesi Sağıık Bilimleri Fakültesi, Sivas, Türkiye

2 Sivas Cumhuriyet Üniversitesi Tıp Fakültesi, Tıp Tarihi ve Etik Anabilim Dalı, Sivas, Türkiye

*Bu çalışma, 29 Haziran-1Temmuz 2017 tarihler arasında Aydın'da düzenlenen 1. Uluslararası Sağlık Bilimleri kongresinde sözlü bildiri olarak sunulmuştur. 
Supportive activities such as seminars and courses are recommended for midwifery students in graduation process towards their altruistic and empathic tendencies. Keywords: Midwifery; Education; Empathy; Altruism.

\section{GIRIS}

Empati yardım edici ilişkinin ve profesyonelliğin önemli bir bileşeni olarak kabul edilmekte, iletişimin sosyal ve duygusal boyutunu oluşturmaktadır $(1,2)$. Bu bağlamda empati, bireyin kendisini karşısındaki insanın yerine koyarak, başkalarının duygularını ve düşüncelerini anlama yeteneği olarak tanımlanmaktadır (3-5). Empati ulaşılması zor bir kavramdır ve duygusal, bilişsel, ahlaki, davranışsal ve ilişkisel boyutlardan oluşmaktadır $(2,5,6)$. Empatik eğilim ise empatinin duygusal boyutunu oluşturmakta ve bireyin empati yapabilme becerisini göstermektedir (7).

Empati kaliteli hasta bakımı, hasta memnuniyeti ve pozitif sağlık sonuçları elde etmek için yaşamsal bir öneme sahiptir (4). Ayrıca empati, sağlık profesyonellerinin iletişimini de kolaylaştıran bir araçtır (8). Ebeler maternal sağlığın korunması ve geliştirilmesinde önemli sağlık profesyonellerinden birini oluşturmaktadır. Ebe tarafından anlaşıldığını hisseden birey önemsendiğini, değer verildiğini ve yalnız olmadığını hisseder (1,9-11). Empatik yaklaşım hastanın daha uyumlu olmasına ve iyileşmesine olumlu katkı sağladığı gibi sağlık profesyonellerinin de mesleki doyum yaşamasına neden olur (12). Hastadaki anksiyete, stres, depresyon ve hostilite duygusunu azaltabilir, benlik kavramını geliştirebilir ve tıbbi hata oranını azaltarak bireylerde gelişebilecek komplikasyon düzeyini düşürebilir $(2,5,6,13)$. Zor ve acı verici durumları kabul etmek, hasta ve ailesi ile de olumlu bir ilişki kurulmasını sağlar. Örneğin "sizin için zor olmalı" gibi basit bir empati ifadesi bile hastanın tepkisinin kabul edilip rahatlamasına yardımcı olabilir (13).

Empati ve özgecilik birbiri ile ilişkili kavramlar olarak belirtilmektedir (14). Özgecilik; merhamete dayanan, kendi çıkarlarından ve beklentilerinden ziyade başkalarının yararına yapılan davranıştır (15-19). Paylaşma, yardım etme, destekleme, koruyup bakım verme gibi sosyal davranışları kapsamakta ve prososyal davranış grubu içerisinde ele alınmaktadır (20). Özgecilik, sağlık bakım uygulamalarında sevgi, merhamet ve sorumluluk duygusu ile ilişkilidir (18) ve profesyonelliğin temel özelliklerinden biridir (15).

Destekleyici ve merhametli olmak etkili bir ebenin temel rolleri arasındadır (10). Özgecilik sağlık profesyonellerinde mesleki bağlılığın ve motivasyonun arttırılması, iş doyumunun sağlanması ve daha az önyargılı olunması açısından önemlidir (17). Ebeler özgeci ve empatik bir tutumla yaklaştıklarında bakım verdikleri bireylerin gereksinimlerini daha doğru saptayabilir, fiziksel ve duygusal durumunu daha kolay anlayabilir ve bakım gereksinimlerini karşılayabilirler $(1,11)$. Primer sağlık profesyonellerinden biri olan ebeler birinci basamak sağlık hizmetlerinde en çok kadın, yenidoğan ve aile bireylerine hizmet vermektedir. $\mathrm{Bu}$ bağlamda kadın, bebek ve aile bireylerinin sorunlarını anlamaları, sorunları erken dönemde fark edebilmeleri, yardımsever ve fedakar olmaları girişimlerin başlatılması açısından önen taşımaktadır. Empatik eğilim ve özgecilik ile kadına ve ailesine ulaşılması, bakımlarının sağlanması daha da kolaylaşır. Böylece bireye özgü bakım da sağlanmış olur (9). Bunların sağlanabilmesi için de öğrencilerin etkili iletişim kurma, karşılık beklemeden yardım etme ve danışmanlık becerilerini eğitimleri süresince öğrenmeleri ve beceri boyutunda kazanmaları istenmektedir $(1,3)$. Ulusal ve uluslararası araştırmalar incelendiğinde öğrencilerin empati $(3,9,10,21)$ ve özgecilik $(20,22,23)$ düzeylerinin genellikle orta düzeyde olduğu görülmektedir.

Türkiye'de Ebelik bölümlerinde öğrenim gören öğrencilerin çoğunluğunun cinsiyeti kadındır. Yapılan araştırmalarda $(5,13)$ kadın öğrencilerin empati düzeylerinin erkeklerden daha yüksek olduğunun saptanması maternal sağlığın geliştirilmesi açısından önemlidir. Literatürde empatinin eğitim ve uygulama yoluyla öğrenilebilen ve geliştirilebilen bir yetenek olduğu belirtilmektedir (1-3,12,13,24). Bu nedenle ebelik öğrencilerinde empatik eğilim ve özgeci yaklaşımın belirlenmesinin, mesleki değerleri öğretmek, iletişim ve yardım etme becerisini geliştirmek açısından yol gösterici olacağ1 düşünülmektedir. Ulusal ve uluslararası araştırmalar incelendiğinde empatik eğilim ve özgecilik ile ilgili hemşirelik öğrencileri ile sınırlı sayıda araştırma $(20,22,23)$ saptanmış olmasına rağmen ebelik öğrencileri ile ilgili araştırmalara rastlanmamıştır. $\mathrm{Bu}$ bağlamda araştırma, geleceğin birer sağlık profesyoneli olacak öğrenci ebelerde empatik eğilim ve özgeciliğin incelenmesi amacı ile yapılmıştır.

\section{GEREÇ VE YÖNTEMLER}

Araştırmanın Tasarımı ve Örneklem: Tanımlayıcı tipteki araştırmanın evrenini 1-30 Mart 2017 tarihleri arasında İç Anadolu Bölgesinde yer alan bir üniversitenin Sağlık Bilimleri Fakültesi Ebelik Bölümü'nde öğrenim görmekte olan 304 öğrenci oluşturmuştur. Araştırmanın örneklemini ise araştırmaya katılmayı kabul eden 251 öğrenci oluşturmuştur. 53 öğrenci araştırmaya katılmayı istemediği ve verilerin toplanma aşamasında ulaşılamadığı için araştırma kapsamı dışında bırakılmıştır (katılım oranı \%82,5'dir).

Veri Toplama Araçları: Araştırmanın verileri, Kişisel Bilgi Formu, Empatik Eğilim Ölçeği ve Özgecilik Ölçeği ile toplanmıştır.

Kişisel Bilgi Formu araştırmacılar tarafından literatür taranarak oluşturulmuştur. Formda öğrencilerin sosyodemografik özelliklerini belirlemek amacıyla yaşı, sınıfı, aile tipi, sosyo-demografik durumu vb. ile ilgili toplam 16 soru bulunmaktadır.

Özgecilik Ölçeği London ve Bower (25) tarafindan 1968 y1lında bireylerin özgecilik düzeylerini belirlemek amacıyla geliştirilmiş, Türkçe'ye uyarlaması Akbaba (26) tarafından 2001 yılında yapılmıştır. Beş dereceli Likert tipi ölçek 20 maddeden oluşmaktadır. Her madde için “çok az-1 puan” ve "çok fazla-5 puan" arasında değerlendirme yapılır. Ölçek; aile, sosyallik, yardımseverlik ve sorumluluk olmak üzere dört alt boyuttan oluşmakta ve her boyutta beş madde bulunmaktadır. Toplam puanın yüksekliği, özgecilik düzeyinin yüksek olduğu göstermektedir. Ölçeğin toplamından alınabilecek en düşük puan 20, en yüksek puan 100'dür (26). Ölçeğin geçerlik ve güvenirlik 
çalışmasında Cronbach Alpha iç tutarlılık katsayısı 0,85 olup, bizim çalışmamızda 0,81 olarak bulunmuştur.

Empatik Eğilim Ölçeği Dökmen (27) tarafindan 1988 yılında geliştirilmiştir. Kişilerin günlük yaşamdaki empati kurma düzeylerini ölçmeyi amaçlayan ölçek, likert tipi ve 20 maddeden oluşmaktadır. Ölçekte her madde için, "tamamen aykırı-1 puan", “oldukça aykırı-2 puan”, “kararsızım-3 puan”, “oldukça uygun-4 puan” ve "tamamen uygun-5 puan” ifadelerinden biri seçilerek değerlendirme yapılır. Ölçekten alınabilecek en düşük puan 20, en yüksek puan 100'dür. Ölçekten elde edilen toplam puanın yüksekliği empatik eğilim düzeyinin yüksek olduğunu göstermektedir (27). Ölçeğin geçerlik ve güvenirlik çalışmasında Cronbach Alpha katsayısı 0,82 olup, bizim çalışmamızda 0,73 olarak bulunmuştur.

Araştırmanın Uygulanması: Araştırmaya katılmayı kabul eden katılımcılara uygulama öncesi araştırma konusu ve amacı hakkında bilgi verilmiş ve bilgilendirilmiş onam formunun okunması sağlanmıştır. Araştırmaya katılmayı kabul eden öğrencilere Kişisel Bilgi Formu, Empatik Eğilim Ölçeği ve Özgecilik Ölçeği araştırmacılar tarafından 1-30 Mart 2017 tarihleri arasında sınıf ortamlarında uygulanmıştır. Veriler eğitimöğretim yılının bahar yarıyılında toplanmıştır. Araştırmada formların doldurulması 10-15 dakika sürmüştür.

Araştırmanın Etik Yönü: Araştırmaya başlamadan önce Üniversitenin Girişimsel Olmayan Klinik Araştırmalar Etik Kurulundan (karar no: 2017-03/10) ve araştırmanın yapıldığı eğitim kurumundan yazılı onay alınmıştır. Araştırmanın amacı ile ilgili öğrencilere bilgi verildikten sonra sözlü ve yazılı onam alınmıştır. Araştırmaya katılım kararının kendilerine ait olduğu, formlar üzerine isim yazılmayacağı, verilerin yalnızca araştırma amacı ile kullanılacağı açıklanmıştır. Araştırma Helsinki Deklerasyon Prensiplerine uygun olarak yapılmıştır.

\section{İstatistiksel Analiz}

Elde edilen veriler SPSS 22.0 programında değerlendirilmiştir. Verilerin normal dağılım gösterip göstermediği Kolmogorov-Smirnov testi ve Shapiro-Wilk testi ile incelenmiştir. Varyans homojenliği Levene testi ile test edilmiştir. Sosyo-demografik özelliklerin değerlendirilmesinde sayı ve yüzdelik dağılım kullanılmıştır. Tanımlayıcı istatistik olarak normal dağılım sağlandığında ortalama ve standart sapma, normal dağılım sağlanmadığında medyan (Q1-Q3) değeri kullanılmıştır. Normal dağılım gösteren verilerde iki grup için bağımsız örneklem t testi, ikiden fazla grup için tek yönlü varyans analizi (ANOVA), farkın hangi gruptan olduğunu belirlemek için Tukey testi uygulanmıştır. Normal dağılım göstermeyen verilerde ise ikiden fazla grup için Kruskal Wallis testi kullanılmıştır. Değişkenler arasındaki ilişki Pearson Korelasyon analizi ile incelenmiş olup, $\mathrm{p}<0,05$ anlamlı olarak kabul edilmiştir.

\section{BULGULAR \\ Sosyo-Demografik Özellikler}

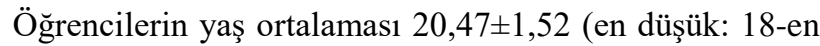
yüksek: 24), \%51,4'ü 18-20 yaş arasındadır. Katılımcıların \%30,3'ü birinci sınıfta öğrenim görmektedir. Öğrencilerin \%98,8'i k1z, \%76,1'i yurtta, \%85,3'ü çekirdek ailede yaşamakta, \%55,8'i aylık gelirinin idare ettiğini belirtmiştir. Katılımcıların \%67,3’ü ebelik mesleğini kendisine uygun bulduğunu, \%52,6's1 akademik başarısını orta olarak değerlendirdiğini ve \%98,8'i empati kavramını bildiğini belirtmiştir. "Hastalarınızı hangi düzeyde anlayabiliyorsunuz" sorusuna ise $\% 51$ 'i hastaları "bazen" anlayabildiğini ifade etmiştir (Tablo 1).

Tablo 1. Öğrencilerin Sosyo-Demografik Özellikleri

\begin{tabular}{|c|c|c|}
\hline Özellikler & & Sayı (\%) \\
\hline Yaş ortalaması & $\begin{array}{l}20,47 \pm 1,52 \\
\text { (aralık:18-24) }\end{array}$ & \\
\hline Yaş & $\begin{array}{l}18-20 \\
21-24\end{array}$ & $\begin{array}{l}129(51,4) \\
122(48,6)\end{array}$ \\
\hline Sinıf & $\begin{array}{l}\text { Birinci } \\
\text { İkinci } \\
\text { Üçüncü } \\
\text { Dördüncü }\end{array}$ & $\begin{array}{l}76(30,3) \\
68(27,1) \\
45(17,9) \\
62(24,7)\end{array}$ \\
\hline Cinsiyet & $\begin{array}{l}\mathrm{K} 1 \mathrm{Z} \\
\text { Erkek }\end{array}$ & $\begin{array}{l}248(98,8) \\
3(1,2)\end{array}$ \\
\hline $\begin{array}{ll}\text { Öğrenimi } & \text { sırasında } \\
\text { yaşadığı yer } & \end{array}$ & $\begin{array}{l}\text { Yurt } \\
\text { Evde arkadaşlar } \\
\text { Aile ile beraber }\end{array}$ & $\begin{array}{l}191(76,1) \\
23(9,2) \\
37(14,7)\end{array}$ \\
\hline Aile tipi & $\begin{array}{l}\text { Çekirdek } \\
\text { Geleneksel }\end{array}$ & $\begin{array}{l}214(85,3) \\
37(14,7)\end{array}$ \\
\hline $\begin{array}{l}\text { Aylık gelirini algılama } \\
\text { durumu }\end{array}$ & $\begin{array}{l}\text { Yeterli } \\
\text { İdare ediyor } \\
\text { Yetersiz }\end{array}$ & $\begin{array}{l}75(29,9) \\
140(55,8) \\
36(14,3\end{array}$ \\
\hline $\begin{array}{l}\text { Mesleği kendine uygun } \\
\text { bulma durumu }\end{array}$ & $\begin{array}{l}\text { Çok uygun } \\
\text { Uygun } \\
\text { Uygun değil }\end{array}$ & $\begin{array}{l}57(22,7) \\
169(67,3) \\
25(10,0)\end{array}$ \\
\hline $\begin{array}{l}\text { Akademik } \quad \text { başarısını } \\
\text { algılama* }\end{array}$ & $\begin{array}{l}\text { İyi } \\
\text { Orta }\end{array}$ & $\begin{array}{l}119(47,4) \\
132(52,6)\end{array}$ \\
\hline Hastaları anlama & $\begin{array}{l}\text { Her zaman } \\
\text { Bazen }\end{array}$ & $\begin{array}{l}123(49,0) \\
128(51,0)\end{array}$ \\
\hline Empati kavramını bilme & $\begin{array}{l}\text { Biliyor } \\
\text { Bilmiyor }\end{array}$ & $\begin{array}{l}248(98,8) \\
3(1,2)\end{array}$ \\
\hline
\end{tabular}

kategorize edilmiş, "kötü" olarak ifade eden olmamıştır. 


\section{Empatik Eğilim ve Özgecilik ile İlgili Bulgular}

Araştırmada Empatik Eğilim Ölçeği toplam puan ortalaması 71,23 7,94 (en düşük: 49; en yüksek: 91) ve toplam özgecilik puan ortalaması $68,42 \pm 9,88$ (en düşük: 36; en yüksek: 89)'dir. Buna göre katılımcıların empatik eğilim ve özgecilik düzeylerinin ortalama değerin üzerinde olduğu saptanmıştır (Tablo 2).

Özgecilik ölçeği alt boyutlarından en fazla aile boyutunda $18,77 \pm 2,87$ (en düşük: 10; en yüksek: 25 ) ve sorumluluk boyutunda $18,62 \pm 2,89$ (en düşük: 8 ; en yüksek: 25 ) puan elde edilmiștir. Daha sonra sırasıyla yardımseverlik boyutundan 16,97 $\pm 3,51$ (en düşük: 5; en yüksek: 25) ve sosyallik boyutundan 14,04 $\pm 4,51$ (en düşük: 5; en yüksek: 25) puan elde edilmiştir (Tablo 2). Ölçeğin tüm alt boyutlarından en düşük 5 , en yüksek 25 puan alınabilmektedir. Buna göre öğrencilerin ailelerini, akrabalarını ve kendilerini yüksek düzeyde yardımsever olarak algıladığı, sorumluluk alma oranının ve başkalarının sorumluluk alabileceğine olan inançlarının da yüksek olduğu bulunmuştur. Ayrıca orta düzeyde başkalarına karşı yardımsever oldukları, sosyal faaliyetlere katıldıkları ve bu faaliyetlerde görev ve sorumluluk üstlendikleri saptanmıştır.

Tablo 2. Empatik Eğilim ve Özgecilik Ölçeği Puanları

\begin{tabular}{|l|l|c|}
\hline Ölçekler & \multicolumn{1}{|c|}{$\begin{array}{l}\text { En düşük- } \\
\text { En yüksek }\end{array}$} & X \pm SS \\
\hline Empatik Eğilim Ölçeği & $\begin{array}{l}49-91^{\mathrm{a}} \\
(20-100)^{\mathrm{b}}\end{array}$ & $71,23 \pm 7,94$ \\
\hline $\begin{array}{l}\text { Özgecilik Ölçeği ve AIt } \\
\text { Boyutları }\end{array}$ & \multicolumn{2}{|l|}{} \\
\hline Aile & $\begin{array}{l}10-25^{\mathrm{a}} \\
(5-25)^{\mathrm{b}}\end{array}$ & $18,77 \pm 2,87$ \\
\hline Sorumluluk & $\begin{array}{l}8-25^{\mathrm{a}} \\
(5-25)^{\mathrm{b}}\end{array}$ & $18,62 \pm 2,89$ \\
\hline Yardımseverlik & $\begin{array}{l}5-25^{\mathrm{a}} \\
(5-25)^{\mathrm{b}}\end{array}$ & $16,97 \pm 3,51$ \\
\hline Sosyallik & $\begin{array}{l}5-25^{\mathrm{a}} \\
(5-25)^{\mathrm{b}}\end{array}$ & $14,04 \pm 4,51$ \\
\hline Toplam özgecilik & $\begin{array}{l}36-89^{\mathrm{a}} \\
(5-25)^{\mathrm{b}}\end{array}$ & $68,42 \pm 9,88$ \\
\hline
\end{tabular}

${ }^{\mathrm{a}}$ Öğrenci ebelerden elde edilen min-max değerler

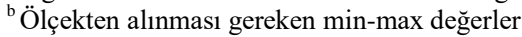

$\mathrm{X} \pm$ SS: Ortalama \pm standart sapma

Öğrencilerin toplam empatik eğilim puanları ile özgecilik ölçeğinin toplam ve alt boyutları arasındaki ilişki Pearson korelasyon analizi ile incelenmiştir. Buna göre özgecilik ölçeği alt boyutlarından aile $(\mathrm{r}=0,235 ; \mathrm{p}<0,001)$, sosyallik $(\mathrm{r}=0,226 ; \mathrm{p}<0,001)$, yardimseverlik $(\mathrm{r}=0,266 ; \mathrm{p}<0,001)$, sorumluluk $(\mathrm{r}=0,235 ; \mathrm{p}<0,001)$ ve toplam özgecilik puanı $(\mathrm{r}=0,335 ; \mathrm{p}<0,001)$ arasında zayıf düzeyde pozitif yönlü istatistiksel olarak anlamlı ilişki saptanmıştır $(p<0,001)$. Öğrencilerin empatik eğilim düzeyleri arttıkça aile, sosyallik, yardımseverlik, sorumluluk ve toplam özgecilik puanları da artış göstermiştir (Tablo 3).
Öğrencilerin öğrenim gördükleri sınıfa göre toplam Empatik Eğilim Ölçeği puanları arasında istatistiksel olarak anlamlı fark olduğu saptanmış olup $(p<0,05)$, birinci sınıf öğrencilerinin dördüncü sınıf öğrencilere göre empatik eğilim düzeyleri daha yüksektir (Tablo 4).

Hastaları anlayabilme becerisine göre toplam Empatik Eğilim Ölçeği, aile, yardımseverlik, sorumluluk ve toplam özgecilik puanları arasında istatistiksel olarak anlamlı fark olduğu $(p<0,05)$ saptanmıștır. Hastaları "her zaman" anlayabildiğini belirten öğrencilerin empatik eğilim, aile, yardımseverlik, sorumluluk ve toplam özgecilik puanları daha yüksek bulunmuştur (Tablo 4).

Öğrencilerin öğrenimi sırasında yaşadığı yere göre özgecilik ölçeğinin alt boyutlarından yardımseverlik, sorumluluk ve toplam özgecilik puanları arasında istatistiksel olarak anlamlı fark olduğu $(p<0,05)$ saptanmıştır. Yurtta yaşayan öğrencilerin evde arkadaşları ve ailesi ile birlikte yaşayan öğrencilere göre toplam özgecilik puanları daha yüksektir. Yurtta ve evde arkadaşları ile birlikte yaşayan öğrencilerin ise ailesi ile birlikte yaşayanlara göre yardımseverlik ve sorumluluk puanları daha yüksek saptanmıștır (Tablo 4).

Öğrencilerin ebelik mesleğini kendisine uygun bulma durumuna göre toplam Empatik Eğilim Ölçeği, özgecilik alt boyutlarından sosyallik, yardımseverlik ve toplam özgecilik puanları arasında istatistiksel olarak anlamlı fark olduğu $(p<0,05)$ saptanmıştır. Ebelik mesleğinin kendisine çok uygun bulduğunu belirten öğrencilerin uygun olmadığını belirten öğrencilere göre empatik eğilim puanları, yardımseverlik ve toplam özgecilik puanları daha yüksektir. Ayrıca çok uygun bulduğunu belirten öğrencilerin özgecilik alt boyutlarından sosyallik puanları da uygun ve uygun olmayanlara göre daha yüksek saptanmıştır (Tablo 4).

\section{TARTIŞMA VE SONUÇ}

Ebelik gibi insanlarla bir arada çalışılması gereken mesleklerde bireyleri ve sorunlarını anlayabilmek için empati ve yardım edici özelliklerin kazanılması gereklidir. $\mathrm{Bu}$ bağlamda empatik eğilim ve yardım edicilik, profesyonel meslek anlayışının ve bakımın kalitesinin odak noktasını oluşturmaktadır. Araştırmada öğrencilerin empatik eğilim ve toplam özgecilik düzeyleri ortalama değerin üzerindedir. Araştırmada elde edilen empatik eğilim $(3,9,10,21,28)$ ve özgecilik $(23,29)$ düzeylerine benzer bulguların elde edildiği çalışmalar literatürde yer almaktadır. Arpacı ve Özmen'in (22) hemşirelik öğrencileri ile yaptığ 1 araştırmada bizim araştırmamızdaki gibi hem özgecilik hem de empatik eğilim değerlerine yakın değerler elde edilmesi araştırma bulgumuzu desteklemektedir. Ebelik öğrencilerinin hasta bakımında temel oluşturacak olan empatik eğilimlerinin ortalama değerin biraz üzerinde elde edilmiş olması, henüz eğitimlerini tamamlamamış, hasta bakımında bağımsız olarak sorumluluk almamış ve meslek yaşantılarının başında olmaları ile açıklanabilir. Bu bulgu öğrencilerin eğitim yaşantıları süresince daha ileri eğitimlerle geliştirilmesi gereksinimini de ortaya koymaktadır. Yapılan araştırmalarda verilen eğitimler ile öğrencilerin empati düzeylerinin artmış olması geliştirilebilecek bir beceri olduğunu da bize göstermektedir $(1,4,12,24)$. 
Tablo 3. Öğrencilerde Özgecilik ve Empatik Eğilim Arasındaki İlişki

\begin{tabular}{|l|l|l|l|l|l|l|}
\hline \multicolumn{2}{|l|}{} & \multicolumn{5}{|c|}{ Özgecilik } \\
\cline { 2 - 7 } \multicolumn{2}{|l|}{} & Aile & Sosyallik & Yardımseverlik & Sorumluluk & Toplam \\
\hline Empatik eğilim & $\mathrm{r}^{\mathrm{a}}$ & $0,235^{\mathrm{b}}$ & $0,226^{\mathrm{b}}$ & $0,266^{\mathrm{b}}$ & $0,235^{\mathrm{b}}$ & $0,335^{\mathrm{b}}$ \\
& $\mathrm{p}$ & $<0,001$ & $<0,001$ & $<0,001$ & $<0,001$ & $<0,001$ \\
\hline
\end{tabular}

${ }^{\mathrm{a}}$ Pearson korelasyon analizi

${ }^{\mathrm{b}}$ Korelasyon 0,001 düzeyinde anlamlıdır.

Tablo 4. Öğrencilerin Özelliklerine Göre Empatik Eğilim ve Özgecilik Puanları

\begin{tabular}{|c|c|c|c|c|c|c|}
\hline \multirow[b]{2}{*}{ Özellikler } & \multirow{2}{*}{$\begin{array}{c}\text { Empatik } \\
\text { eğilim } \\
\mathrm{X} \pm \mathrm{SS}\end{array}$} & \multirow{2}{*}{$\begin{array}{c}\text { Toplam } \\
\text { özgecilik } \\
\text { X } \pm S S\end{array}$} & \multicolumn{4}{|c|}{ Özgecilik ölçeği alt boyutları } \\
\hline & & & $\begin{array}{c}\text { Aile } \\
\mathrm{X} \pm \mathrm{SS}\end{array}$ & $\begin{array}{c}\text { Sosyallik } \\
\mathrm{X} \pm \mathrm{SS}\end{array}$ & $\begin{array}{c}\text { Yardımseverlik } \\
\mathrm{X} \pm \mathrm{SS}\end{array}$ & $\begin{array}{c}\text { Sorumluluk } \\
\mathrm{X} \pm \mathrm{SS}\end{array}$ \\
\hline $\begin{array}{l}\text { Sinıfi } \\
\text { Birinci } \\
\text { İkinci } \\
\text { Üçüncü } \\
\text { Dördüncü } \\
\text { p / F }\end{array}$ & $\begin{array}{c}73,03 \pm 8,15 \\
70,80 \pm 6,89 \\
71,80 \pm 8,39 \\
69,06 \pm 8,01 \\
\mathbf{0 , 0 2 9} * / 3,067\end{array}$ & $\begin{array}{c}68,61 \pm 9,45 \\
69,41 \pm 9,36 \\
69,13 \pm 10,76 \\
66,59 \pm 10,29 \\
0,385 / 1,019\end{array}$ & $\begin{array}{c}18,40 \pm 2,77 \\
19,00 \pm 2,59 \\
19,37 \pm 2,88 \\
18,54 \pm 3,24 \\
0,261 / 1,344\end{array}$ & $\begin{array}{c}14,47 \pm 4,08 \\
13,88 \pm 4,51 \\
14,04 \pm 5,17 \\
13,70 \pm 4,58 \\
0,776 / 0,369\end{array}$ & $\begin{array}{c}17,17 \pm 3,34 \\
17,54 \pm 3,76 \\
16,73 \pm 3,89 \\
16,29 \pm 3,06 \\
0,205 / 1,537\end{array}$ & $\begin{array}{c}18,56 \pm 2,61 \\
18,98 \pm 3,07 \\
18,97 \pm 2,60 \\
18,04 \pm 3,16 \\
0,240 / 1,412\end{array}$ \\
\hline $\begin{array}{l}\text { Hastaları } \\
\text { anlama } \\
\text { Her zaman } \\
\text { Bazen } \\
\text { p / t }\end{array}$ & $\begin{array}{c}73,43 \pm 7,59 \\
69,11 \pm 7,72 \\
0,001 * / 4,461\end{array}$ & $\begin{array}{c}70,26 \pm 9,72 \\
66,65 \pm 9,75 \\
0,004 * / 2,937\end{array}$ & $\begin{array}{c}19,18 \pm 2,67 \\
18,38 \pm 3,01 \\
0,026 * / 2,232\end{array}$ & $\begin{array}{c}14,34 \pm 4,90 \\
13,76 \pm 4,10 \\
0,313 / 1,010\end{array}$ & $\begin{array}{c}17,61 \pm 3,52 \\
16,35 \pm 3,40 \\
0,004 * / 2,876\end{array}$ & $\begin{array}{c}19,12 \pm 2,76 \\
18,14 \pm 2,94 \\
0,007 * / 2,697\end{array}$ \\
\hline & $\begin{array}{l}\text { Ortanca } \\
\text { (Q1-Q3) }\end{array}$ & $\begin{array}{l}\text { Ortanca } \\
\text { (Q1-Q3) }\end{array}$ & $\begin{array}{l}\text { Ortanca } \\
\text { (Q1-Q3) }\end{array}$ & $\begin{array}{l}\text { Ortanca } \\
\text { (Q1-Q3) }\end{array}$ & $\begin{array}{l}\text { Ortanca } \\
\text { (Q1-Q3) }\end{array}$ & $\begin{array}{l}\text { Ortanca } \\
\text { (Q1-Q3) }\end{array}$ \\
\hline \multicolumn{7}{|c|}{ Öğrenimi sırasında yaşadığı yer } \\
\hline $\begin{array}{l}\text { Yurt } \\
\text { Evde } \\
\text { arkadaşlar ile } \\
\text { Aile ile } \\
\text { p / KW }\end{array}$ & $\begin{array}{c}72,00 \\
(65,00-77,00) \\
71,00 \\
(65,00-74,00) \\
72,00 \\
(67,50-76,00) \\
0,907 / 0,195\end{array}$ & $\begin{array}{c}69,00 \\
(63,00-77,00) \\
65,00 \\
(60,00-76,00) \\
65,00 \\
(57,00-72,00) \\
0,020 * / 7,820\end{array}$ & $\begin{array}{c}19,00 \\
(17,00-21,00) \\
20,00 \\
(17,00-22,00) \\
18,00 \\
(17,00-20,00) \\
0,796 / 0,457\end{array}$ & $\begin{array}{c}15,00 \\
(11,00-17,00) \\
14,00 \\
(10,00-17,00) \\
13,00 \\
(10,50-15,50) \\
0,096 / 4,680\end{array}$ & $\begin{array}{c}17,00 \\
(15,00-20,00) \\
17,00 \\
(14,00-18,00) \\
16,00 \\
(12,50-18,50) \\
0,033 * / 6,850\end{array}$ & $\begin{array}{c}19,00 \\
(17,00-21,00) \\
19,00 \\
(15,00-21,00) \\
18,00 \\
(15,50-19,00) \\
0,038 * / 6,564\end{array}$ \\
\hline \multicolumn{7}{|c|}{ Mesleği kendine uygun bulma } \\
\hline $\begin{array}{l}\text { Çok uygun } \\
\text { Uygun } \\
\text { Uygun değil } \\
\text { p / KW }\end{array}$ & $\begin{array}{c}73,00 \\
(69,50-79,50) \\
71,00 \\
(65,00-76,50) \\
69,00 \\
(61,00-73,50) \\
0,007 * / 9,95\end{array}$ & $\begin{array}{c}73,00 \\
(64,50-80,00) \\
69,00 \\
(61,00-75,00) \\
67,00 \\
(60,00-73,00) \\
0,020 * / 7,779\end{array}$ & $\begin{array}{c}19,00 \\
(17,00-21,00) \\
19,00 \\
(17,00-21,00) \\
19,00 \\
(17,00-21,50) \\
0,941 / 0,122\end{array}$ & $\begin{array}{c}16,00 \\
(13,00-20,00) \\
14,00 \\
(10,00-16,00) \\
14,00 \\
(10,50-17,50) \\
0,003 * / 11,846\end{array}$ & $\begin{array}{c}18,00 \\
(15,50-21,00) \\
17,00 \\
(15,00-19,00) \\
16,00 \\
(13,50-18,50) \\
0,004 * / 10,963\end{array}$ & $\begin{array}{c}18,00 \\
(17,00-21,00) \\
19,00 \\
(17,00-21,00) \\
19,00 \\
(17,00-19,50) \\
0,661 / 0,827\end{array}$ \\
\hline
\end{tabular}

$\mathrm{X} \pm \mathrm{SS}$ : Ortalama \pm standart sapma; F: Tek yönlü varyans analizi (ANOVA); t: Bağımsız örneklem t testi; KW: Kruskal Wallis testi; Q1-Q3: 1. ve 3. kartil değerleri; *p<0,05

Bununla beraber Williams ve arkadaşları (13) ebelik öğrencilerinin, McKenna ve arkadaşları (8) ve Petrucci ve arkadaşları (6) hemşirelik öğrencilerinin empati düzeylerini iyi düzeyde, Johnson ve arkadaşları (15) hemşirelik öğrencilerinin özgecilik düzeylerini düşük olarak saptaması araştırma bulgumuz ile farklılık göstermiştir. Bunun nedeni kültürel özelliklerin, eğitim ortamının ve örneklem gruplarının farklı olması ile açıklanabilir.

Araştırmamızda empatik eğilimin artması ile özgeciliğin de arttığ 1 saptanmıştır. Literatürde de empati ile özgecilik arasında bir ilişkinin var olduğu belirtilmektedir $(14,30)$. Duyguları anlama-duygusal yaşantılardan etkilenme, başkalarının sorununu fark etme ve sonuçta başkalarına daha fazla yardım edebilme isteği empatik eğilimi yüksek olan kişilerde daha fazla olabilmektedir (7). Özgecilik, empatik deneyimlere yönelik doğrudan ortaya çıkan olumlu davranışlardır (14). Araştırmamızdan elde edilen bulgu, empati ile özgecilik arasında ilişki olduğunu ortaya koyan diğer araştırmalar $(20,22,31,32)$ ile tutarlılık göstermiştir. 
188 çalışan ve hemşirelik öğrencisi ile yapılan bir araştırmada başkalarına yarar sağlayan, gönüllü olarak gerçekleştirilen davranışlardan oluşan ve prososyal davranış grubu içinde ele alınan özgecilik arasında ilişki saptanmıştır (33). Hemşirelik öğrencileri ile yapılan başka bir araştırmada da algılanan empatik öz yeterlilik eğilimleri ile özgecilik düzeyleri arasında pozitif yönde ve istatistiksel olarak anlamlı bir ilişkinin bulunması araştırma bulgumuz ile uyumludur (34). Ayrıca sosyal hizmet bölümü öğrencilerinde de benzer şekilde empatik eğilimleri ile özgecilik düzeyleri arasında orta düzeyde ve pozitif yönde anlamlı bir ilişki olduğu saptanmıştır (35). Ebelik, hemşirelik, sosyal hizmet uzmanlığı gibi meslekler insana hizmet eden, insanların sorunlarına yardımcı olan, insanın fiziksel, ruhsal ve sosyal sağlığını koruyucu, önleyici ve geliştirici yönde bakım sağlayan mesleklerdir. $\mathrm{Bu}$ meslek gruplarında empati ve özgeciliğin ilişkili bulunması eğitim müfredatının içeriği, temelde insana hizmet vermesi ve öğrencilerin insancıl bakış açısına sahip olmaları ile ilişkili olabilir. Empatik eğilimin eğitim programları ile yükseldiğini gösteren çalışmalar $(1,4,12,13,24,36)$ doğrultusunda verilecek eğitimlerin empatik eğilim ve özgecilik arasındaki ilişkinin artışına katkı vereceği düşünülmektedir.

Araştırmada birinci sınıf öğrencilerin dördüncü sınıf ögrencilere göre empatik eğilim düzeyleri daha yüksektir. Araştırma verileri 2016-2017 eğitim-öğretim yılının bahar döneminde elde edilmiştir. Birinci sınıf öğrencilerinde empatik eğilimin yüksek olması araştırmanın yapıldığı dönemde "Ebelikte Kişilerarası İlişkiler" dersinin veriliyor olması ile ilişkilendirilebilir. Öğrenciler ayrıca bu dönemde mesleki dersler ile yeni karşılaştıkları için meslek ile ilgili konulara daha ilgili olabilmektedir. Dördüncü sınıfta ise empatik eğilimlerinin düşük olması, mezuniyet aşamasında ve sadece yapacakları teknik uygulamalara odaklanarak bütüncül yaklaşımdan uzaklaşmış olmalarına bağlanabilir. Sınıf düzeyi ilerledikçe öğrenciler, artan iş yükü, yorucu klinik ortam ve hümanistik olmayan uygulamalarla karşılaşabilmektedir. Sonuç olarak bu faktörler duygusal baskılanma, hastalardan kopma, tükenmişlik ve empati yapma becerisinde azalmaya yol açabilmektedir (37). Bu da bize özellikle mezuniyet aşamasında empatinin tekrar ele alınmasının ve üzerinde durulmasının gerekliliğini göstermektedir. Yapılan bir çalışmada araştırma bulgumuz ile benzer bulguların elde edilmesi araştırmamız ile paralellik göstermiştir (11). Fakat literatürde yıllara göre anlamlı fark olmadığını gösteren bazı araştırmaların olduğu da görülmektedir $(8,38,39)$. Farklı bulgular elde edilmesinin nedeni örneklem gruplarının farklığı ve kadın cinsiyetin araştırmada ağırlıklı olması ile açıklanabilir.

Hastaları "her zaman" anlayabildiğini belirten öğrencilerin hem empatik eğilim hem de aile, yardımseverlik, sorumluluk ve toplam özgecilik puanları daha yüksektir. Literatürde empati kurmakla yardım edicilik arasında olumlu bir ilişki bulunduğu belirtilmektedir. Empatik eğilimleri yüksek bireyler başkalarının içinde bulunduğu psikososyal durumu daha kolay algilayabilmekte ve özgeci davranabilmektedir (20,30). Empati yapma becerisi yüksek olan bireyler, yardım gerektirecek bir durumla karşılaştıklarında onları zorlayacak ya da rahatını bozacak bir durum olsa dahi yardımcı olabilmektedirler (30). Yapılan bir araştırmada da hastayı genellikle anlayabildiğini belirten hemşirelik öğrencilerinin puanlarının daha yüksek bulunması araştırmamızdan elde edilen bulgular ile tutarlıdır (22).

Araştırmamızda yurtta yaşayan öğrencilerin evde arkadaşları ve ailesi ile birlikte yaşayan öğrencilere göre toplam özgecilik puanları daha yüksek bulunmuştur. Ayrıca yurtta ve evde arkadaşları ile birlikte yaşayan öğrencilerin ailesi ile birlikte yaşayanlara göre yardımseverlik ve sorumluluk puanları daha yüksektir. $\mathrm{Bu}$ bulgu öğrencilerin başkalarına karşı yardımsever ve sorumlu davranacaklarına, başkalarının da sorumluluk alabileceklerine olan inançlarının daha yüksek olduğunu göstermektedir. Ayrıca elde edilen bulgu öğrencilerin kalabalık bir grup içinde diğer öğrenciler ile beraber yaşamaları, yaşamlarını sürdürebilmek için paylaşımcı olmak durumunda olmaları ve başkalarına karşı yardım etme durumunu olumlu yönde geliştirdiklerini düşündürmektedir. Hemşirelik öğrencileri ile yapılan bir araştırmada geleneksel ailede yaşamanın, kardeş sayısı ve arkadaş sayısının fazla olmasının özgecilik düzeylerini arttıran bir faktör olduğunun bulunması araştırma bulgumuzu desteklemektedir (29). Benzer şekilde Avcı ve arkadaşlarının (20) çalışmasında da on bir ve üzerinde yakın arkadaşı olan öğrencilerin özgecilik puanları daha yüksek bulunmuştur. Bu bulgular araştırmamızdan elde edilen bulgumuzu desteklemektedir.

Ebelik mesleğinin kendisine çok uygun olduğunu belirten öğrencilerin empatik eğilimleri, özgecilik alt boyutlarından sosyallik, yardımseverlik ve toplam özgecilik puanları daha yüksektir. Rognstad, Nortvedt ve Aasland (40) hemşirelik öğrencilerinin, yardım etme motivasyonunun etkisini inceledikleri çalışmada, öğrencilerin hem özgeci olmak hem de yardım ettikleri hastalardan olumlu geribildirim almayı istedikleri, olumlu geribildirimlerin de özgeci bakımın sağlanmasında önemli bir etken olduğu saptanmıştır. Başka bir çalışmada da hemşirelik bölümünü seçtiği için memnun olan öğrencilerin empatik eğilim, sosyallik, yardımseverlik ve toplam özgecilik puanlarının yüksek bulunması araştırma bulgumuzu desteklemektedir (22). Ouzouni and Nakakis (3) mesleği isteyerek seçen ve mezun olduktan sonra mesleğini yapmak isteyen öğrencilerin empati düzeylerinin daha yüksek olduğunu saptaması da araştırma bulgumuz ile benzerlik göstermiştir. Duru'nun (31) yaptığı çalışmada; mesleği isteyerek seçen öğrencilerin yardım eğilimlerinin daha yüksek olduğu belirlenmiştir. Bölüme isteyerek gelen sosyal hizmet bölümü öğrencilerinin de özgecilik puanları daha yüksek bulunmuştur (35). Bunun nedeninin sosyal hizmet bölümü öğrencilerinin de insana hizmet eden bir meslek grubu olmasından kaynaklandığı düşünülmektedir. Fakat Pehlivan ve Lafcı'nın (23) araştırmasında mesleği isteyerek seçen hemşirelik öğrencilerinde toplam özgecilik, alt boyutlardan sosyallik ve yardımseverlik puanları daha yüksek olmakla beraber anlamlı bulunmamıştır. Bunun nedeni ise örneklem gruplarının farklı olması ile açıklanabilir.

$\mathrm{Bu}$ araştırmanın birkaç sınırlılığı bulunmaktadır. $\mathrm{Bu}$ araştırmadan elde edilen bulgular sadece araştırmanın yapıldığ1 üniversitenin ebelik bölümünde öğrenim görmekte olan öğrencileri kapsamaktadır, diğer ebelik 
öğrencileri ile genelleme yapılamaz. Ayrıca bu araştırma tanımlayıcı bir araştırmadır.

Öğrenci ebelerde empatik eğilimin artması ile özgecilik de artmaktadır. Mesleği kendine uygun bulma ve hastaları anlayabilme becerisi öğrencilerin hem empatik eğilimlerini hem de özgecilik düzeylerini, öğrenim gördükleri sınıf düzeyi empatik eğilimlerini, yaşadıkları ortam ise özgecilik düzeylerini etkilemektedir. Bu doğrultuda öğrencilerin hasta bakımında empatik ve özgeci davranışlar sergileyebilmeleri için; öncelikle üniversiteye giriş sınavında mesleği kendisine uygun bulan öğrencilerin ebelik mesleğini tercih etmesi, teori ve uygulamalarda empatik ve yardım edicilik becerilerinin desteklenmesi, empatik ve yardım edicilik becerilerine yönelik seminer, kurs gibi aktivitelerin yapılması, özellikle son sınıf öğrencilerinin empati becerilerinin desteklenmesi önerilmektedir.

Yazarların Katkıları: Fikir: Ş.E.P., G.Y.; Tasarım: Ş.E.P., G.Y.; Denetleme: Ş.E.P., G.Y.; Kaynaklar: Ş.E.P., G.Y.; Veri Toplama: Ş.E.P.; Analiz ve Yorum: Ş.E.P.; Literatür Taraması: Ş.E.P.; Yazıyı Yazan: Ş.E.P.; Eleştirel İnceleme: Ş.E.P., G.Y.

\section{KAYNAKLAR}

1. Cunico L, Sartori R, Marognolli O, Meneghini AM. Developing empathy in nursing students: a cohort longitudinal study. Journal of Clinical Nursing. 2012; 21(13-14): 2016-25. doi:10.1111/j.13652702.2012.04105.x.

2. Fields SK, Mahan P, Tillman P, Harris J, Maxwell K, Hojat M. Measuring empathy in health care profession students using the Jefferson Scale of Physician Empathy: health provider - student version. Journal of Interprofessional Care. 2011; 25(4): 287-93. doi:10.3109/13561820.2011.566648.

3. Ouzouni C, Nakakis K. An exploratory study of student nurses' empathy. Health Science Journal. 2012; 6(3): 534-52.

4. vanVliet M, Jong M, Jong MC. Long-term benefits by a mind-body medicine skills course on perceived stress and empathy among medical and nursing students. Medical Teacher. 2017; 39(7): 710-9. doi:10.1080/0142159X.2017.1309374.

5. Wilson SE, Prescott J, Becket G. Empathy levels in first- and third-year students in health and non-health disciplines. American Journal of Pharmaceutical Education. 2012; 76(2): 1-4. doi:10.5688/ajpe76224.

6. Petrucci C, La Cerra C, Aloisio F, Montanari P, Lancia L. Empathy in health professional students: a comparative cross-sectional study. Nurse Education Today. 2016; 41: 1-5. doi:10.1016/j.nedt.2016.03.022.

7. Sabancıŏulları S, Kelleci M, Doğan S, Gölbaşı Z. Entegre eğitim programında eğitim gören hemşirelik öğrencilerinin empatik eğilim düzeylerinin yıllara göre incelenmesi. Cumhuriyet Üniversitesi Hemşirelik Yüksekokulu Dergisi. 2007; 11(2): 1-6.

8. McKenna L, Boyle M, Brownet $\mathrm{T}$, Williams $\mathrm{B}$, Molloy A, Lewis B, et al. Levels of empathy in under graduate nursing students. International Journal of Nursing Practice. 2012; 18(3): 246-51. doi:10.1111/j.1440-172X.2012.02035.x.
9. Bekmezci H, Yurttaş CB, Özkan H. Ebelik bölümü öğrencilerinin empatik eğilim düzeylerinin belirlenmesi. HSP. 2015; 2(1): 46-54.

10. McKenna L, Boyle M, Brownet T, Williams B, Molloy A, Lewis B, et al. Levels of empathy in under graduate midwifery students: an Australian cross-sectional study. Women and Birth. 2011; 24(2): 80-4. doi:10.1016/j.wombi.2011.02.003.

11. Ozcan CT, Oflaz F, Sutcu Cicek H. Empathy: the effects of under graduate nursing education in Turkey. International Nursing Review. 2010; 57(4): 493-9. doi:10.1111/j.1466-7657.2010.00832.x.

12. Bas-Sarmiento $\mathrm{P}$, Fernández-Gutiérrez $\mathrm{M}$, BaenaBaños M, Baena-Bañosa M. Efficacy of empathy training in nursing students: a quasi-experimental study. Nurse Education Today. 2017; 59: 59-65. doi:10.1016/j.nedt.2017.08.012.

13. Williams B, Brown T, Boyle M, McKenna L, Palermo C, Etherington J. Levels of empathy in undergraduate emergency health, nursing, and midwifery students: a longitudinal study. Advances in Medical Education and Practice. 2014; 5: 299306. doi:10.2147/AMEP.S66681.

14. McCamant KL. Humanistic nursing, interpersonal relations theory, and the empathy-altruism hypothesis. Nursing Science Quarterly. 2006; 19(4): 334-8. doi:10.1177/0894318406292823.

15. Johnson M, Haigh C, Yates-Balton N. Valuing of altruism and honesty in nursing students: a two decade replication study. Journal of Advanced Nursing. 2007; 57(4): 366-74. doi:10.1111/j.13652648.2006.04119.x.

16. Mcgaghie WC, Mytko JJ, Brown WN, Cameron JR. Altruism and compassion in the health professions: a search for clarity and precision. Medical Teacher. 2002; 24(4): 374-8. doi:10.1080/01421590220145734.

17. Nasrabadi AN, Forooshani ZSD, Rafiee F. Altruism the essense of the Iranian nurses' job satisfaction: a qualitative study. Global Journal of Health Science. 2016; 8(8): 13-9.

18. Slettmyr A, Schandl A, Arman M. The ambiguity of altruism in nursing: a qualitative study. Nursing Ethics. 2019; 26(2): 368-77. doi:10.1177/0969733017709336.

19. Swank JM, Robinson EHM, Ohrt JH. Manifestation of altruism: perceptions among counselling students in the United Kingdom. Counselling and Psychotherapy Research. 2012; 12(1): 63-70. doi:10.1080/14733145.2011.562981.

20. Avcı D, Aydın D, Özbaşaran F. Hemşirelik öğrencilerinde empati-özgecilik ilişkisi ve özgeci davranışın bazı değişkenler açısından incelenmesi. Balıkesir Sağlık Bilimleri Dergisi. 2013; 2(2): 10813.

21. Arifoglu B, Razı GS. Birinci sınıf hemşirelik öğrencilerinin empati ve iletişim becerileriyle iletişim yönetimi dersi akademik başarı puanı arasındaki ilişki. DEUHYO ED. 2011; 4(1): 7-11.

22. Arpacı P, Özmen D. Hemşirelik öğrencilerinin özgecilik ve empatik eğilim düzeyleri ve aralarındaki ilişki. Hemşirelikte Eğitim ve Araştırma Dergisi. 2014; 11(3): 51-7. 
23. Pehlivan S, Lafçı D. Hemşirelik öğrencilerinin özgecilik düzeyleri. Gaziantep Medical Journal. 2014; 20(1): 29-34.

24. Sheehan CA, Perrin KO, Potter ML, Kazanowski MK, Bennett LA. Engendering empathy in baccalaureate nursing students. International Journal of Caring Sciences. 2013; 6(3): 456-64.

25. London P, Bower R. Altruism, extra version and mental illness. The Journal of Social Psychology. 1968; 76(1): 19-30. doi:10.1080/00224545.1968.9919819.

26. Akbaba S. Özgecilik ölçeğinin Türkçeye uyarlanması geçerlik ve güvenirlik çalışması. Atatürk Üniversitesi Erzincan Eğitim Fakültesi Dergisi. 2001; 3(2): 8595.

27. Dökmen U. Empatinin yeni bir modele dayanılarak ölçülmesi ve psikodrama ile geliştirilmesi. Ankara Üniversitesi Eğitim Bilimleri Fakültesi Dergisi. 1988; 21(1): 155-90. doi: 10.1501/Egifak_0000000999.

28. Uncu F, Açık Y, Deveci SE, Çelebi E, Oğuzöncül AF, Ulaş B. Sağlık Yüksekokulunda öğrenim gören hemşirelik öğrencilerinin empatik eğilim ve empatik beceri düzeylerinin belirlenmesi. Yıldırım Beyazıt Üniversitesi Sağlık Bilimleri Fakültesi Hemşirelik EDergisi. 2015; 3(3): 1-8.

29. Kaçar Banbal G. Hemşirelik öğrencilerinin özgecilik düzeyleri [Yüksek Lisans Tezi]. İstanbul: İstanbul Üniversitesi; 2010.

30. Öz F. Hemşirelikte özgecilik (yardım edicilik). Cumhuriyet Üniversitesi Hemşirelik Yüksekokulu Dergisi. 1998; 2(1): 53-8.

31. Duru E. Öğretmen adaylarında empati-yardım etme eğilimi ilişkisi ve yardım etme eğiliminin bazı psikososyal değişkenler açısından incelenmesi. Pamukkale Üniversitesi Eğitim Fakültesi Dergisi. 2002; 12(12): 21-35.

32. Tekeş B, Hasta D. Özgecilik ölçeği: geçerlik ve güvenirlik çalışması. Nesne Psikoloji Dergisi (NPD). 2015; 3(6): 55-75. doi:10.7816/nesne-03-06-03.

33. González-Serna JMG. Nursing empathy and prosociality: the relationship. Journal of Nursing. 2018; 7(1): 1-7.

34. Yıldırım Keskin A, Berk Özcan Ç. Hemşirelik öğrencilerinin özgecilik, empatik ve sosyal öz yeterlilik eğilim düzeylerinin incelenmesi. Turkiye Klinikleri. 2018; 10(2): 122-9. doi:10.5336/nurses.2018-60106.

35. Acar MC, Apak H. Sosyal hizmet bölümü öğrencilerinin empatik eğilimleri ile özgecilik düzeyleri arasındaki ilişkinin incelenmesi. Toplum ve Sosyal Hizmet. 2017; 28(1): 93-112.

36. Tafazoli M, Ezzati R, Mazlom SR, Asgharipour N. The effect of empathy training on empathic skills of midwifery students. Journal of Midwifery and Reproductive Health. 2018; 6(2): 1236-43. doi: 10.22038/JMRH.2018.10214.

37. Burks DJ, Kobus AM. The legacy of altruism in health care: the promotion of empathy, prosociality and humanism. Medical Education. 2012; 46(3): 317-25. doi:10.1111/j.1365-2923.2011.04159.x.

38. Brown T, Williams B, Boyle M, Molloy A, McKenna L, Molloy L, et al. Levels of empathy in under graduate occupational therapy students. Occupational Therapy International. 2010; 17(3): 135-41. doi:10.1002/oti.297.

39. Lauder W, Reynolds W, Smith A, Sharkey S. A comparison of therapeutic commitment, role support, role competency and empathy in three cohorts of nursing students. Journal of Psychiatric and Mental Health Nursing. 2002; 9(4): 483-91. doi:10.1046/j.1365-2850.2002.00510.x.

40. Rognstad M-K, Nortvedt P, Aasland O. Helping motives in late modern society: values and attitudes among nursing students. Nursing Ethics. 2004; 11(3): 227-39. doi:10.1191/0969733004ne691oa. 